\title{
Education and National Security: Challenges and the Way Forward
}

\author{
Orikpe, Ephraim Azubike
}

Federal College of Education (Technical)

Umunze, Anambra State, Nigeria

\section{Doi:10.5901/jesr.2013.v3n10p53}

\begin{abstract}
This paper critically examined the many security challenges bedeviling the nation government has tried in many ways to contain the situation including increased budgetary allocation of funds to the security sector, to "ensure the security of lives and property". However, the extra budgetary expense on "security" has not succeeded in dousing the security challenges in the country. The paper identifies reform of the education system as a panacea to the lingering security challenges confronting the nation in the long run. Useful recommendations were made.
\end{abstract}

\section{Introduction}

National integration covers all activities and arrangements put in place to ensure free movement, mixing and interaction of a people of a nation with other people of the same nation without any form of gender, racial, tribal or religious discrimination. Happenings in recent times in the nation have once again called for sober reflection by all particularly, in view of the dynamics of our federation. National security is in jeopardy. Insecurity comes in different coloration and magnitude among which include the spate of bombings in some parts of the country, election related crises, kidnapping, human trafficking, militancy, assassination, hunger, armed robbery, environmental degradation and other untoward acts now being experienced in the country. All these have thrown up the need for all and sundry to be more retrospective, introspective and proactive on issues of national security so as to arrest this negative drift currently impacting our national psyche. Some of these security issues have been with us for sometime now without fizzling out despite concerted efforts to the contrary. There is therefore the need to try the education option as a panacea for assuaging the drift thereby guaranteeing national security.

Education has been defined as a process by which individuals are assisted formally through proper direction and guidance to develop their capacities for their own benefit and that of the society (Okeke, 2003). It is geared towards developing the individuals for them to live effectively and efficiently in the society and to contribute to its advancement and upliftment. Hence, through education the behaviour patterns of the citizens could be changed in the desired direction. In other words, with sound education people will start to understand and appreciate one another better and try to restore the dignity of man. Hence, we have to recognize the role education plays in equipping individuals with requisite knowledge and skills for survival and societal progress.

Successive Nigerian governments have evolved different policies and programmes to promote education and develop the nation's human resources, (Matawal, 2007). Often, these reforms in education fail to provide broad-based education in the development of the mind, in comprehending the environment and development of appropriate skills, abilities and competencies to co-exist with and contribute to the development of the society. It is meaningless to talk of development in the absence of national security. In other words, insecurity in a nation is a threat to development. There is therefore, a nexus between national security and development. In a state of insecurity, development is as elusive as a mirage. 


\section{National Security Challenges}

National security is a top public issue today. It is a matter of national importance that should be of concern to all stakeholders in the Nigerian State and one that requires comprehensive and committed contribution of all groups and interests that make up Nigeria. National security can not be narrowed down to defense and military might alone. It is wider than that. It is this narrow conception of national security that forms the basis for the disproportionate budgetary allocation of funds as the case is, to "ensure the security of lives and property", however, to the utter neglect of other equally important sectors of the economy that bear directly or indirectly on national security. Such sectors as education, health, agriculture etc become poorly mobilized.

I redia (2011) defined national security as the ability of a State to overcome any form of its challenges no matter what the challenge is. He averred that national security is wider than military might, defense or law enforcement and pointed out other rather basic dimensions like job, water and food security. It is appropriate therefore, to state at this juncture that a national security policy would be of no use to the unemployed and hungry citizens that constitute the majority of the population in a poor country like ours. To lay credence to the all inclusive nature of the meaning of national security, the American President Barack Obama in 2010 canvassed an all-encompassing world view in his own definition of America's national security interests which include, "a strong, innovative and growing U.S. economy in an open international economic system that promotes opportunity and prosperity".

Similarly, Abubakar (2005) averred that recent international debates have raised the need to see security in the broader sense as "the struggle to secure the

most basic necessities of life such as food, fuel, medicine and shelter". This broader view of security from the perspective of human physiological needs is important for the attainment of physical and national security and overall peace and development, as social unrest arising from the absence of such basic-human security can indeed lead to security problems and conflicts. Apart from the socio-economic security challenges, Abubakar (2005) identified some of the major security challenges confronting the nation to include political and electioneering conflicts, ethno-religious crises, ethnic militias, boundary disputes, cultism, criminality and organized crimes. In the same vane, Oshio (2009) opined that

Nigeria is today plagued with social disorder, insecurity, poverty, illiteracy, balance of payment deficit, poor health statistics, ethnic and religious conflicts, corruption, crime and criminality and political crises. All these mean that we are very insecure in terms of human wellbeing. The problems, individually and collectively constitute threats to the peace, security and development of the country. Invariably, they have implications for the continuity and survival of the nation's nascent democracy.

Oshio was of the view that the term "national security" does not appear to lend itself to any precise definition partly because its nature and concept may vary from one state to the other. He however identified two main tendencies in defining it:

a. The first is the state-centered concept which views national security in terms of defense and survival of the state.

This conception according him-

i. Equates "defense" with "security" and bestows its protection to the military as the custodians of national security and

ii. Equates national security with the security of the state.

Iredia (2011) sees this conception as microscopic and quickly points out that national security cannot be equated to military might, defense or law enforcement alone. It goes beyond that to accommodate far more reaching issues. Elaborating more on this, Esiemokhai (2010) averred that in states where the interest of the ruling elite is put above that of the people, the police, the army and security formations are expected to defend the government, its personnel and its property. 
b. The second tendency in the definition of national security, according to Oshio (2009), involves the factoring of the state and individual into the constituents of the definition. Here, security involves freedom from danger or threat to a nation's ability to protect its cherished values and well-being of its people.

This second conception takes into consideration the significance of human well-being in the security considerations of a country. In states where the people's welfare, well-being and wholesomeness are the paramount concern of the state, the government, determinedly weaves a security network around the people in the various villages, towns and cities. Oshio opines that it is advisable to view security in a state with nationality crises in terms of contending groups, organizations and individuals, as prime object of security. This dispenses with the narrow-minded conception of a national security primarily from its military- strategic dimension particularly in terms of defending its territory and sovereignty.

Recent social unrests in various African countries no doubt have roots in the failure of the government policies to provide or manage the basic human physiological needs of their citizens. In recent times, Nigeria has witnessed increasing number of security challenges that constitute threats to the cooperate, existence of its citizens and to the maintenance and survival of its democratic political system. These security challenges are diverse and complex, ranging from political disagreements to criminal activities with alarming dimensions and consequences. The spate of target bombings by the Boko Haram sect is a big security challenge to the Federal government, the affected states and the entire nation. This position was attested to by the declaration of Inuwa Bwala (Borno State Information Commissioner) in a recent interview granted by the Daily Sun (2012) that "the Boko Haram issue is not just a Borno problem. It is a Nigerian problem, it is a subregional problem".

When Boko Haram first started their attacks in some parts of the North, some leaders explained away their actions but now, the stark reality seems to have dawned on all. The Boko Hararn crises are moving from one dimension to another, destroying human lives, properties and the economy of Nigeria. Major among them are the suicide bombing of the United Nation's building in Abuja, the Police Force Headquarters bombing, the $25^{\text {th }}$ December 2011 bombing of St. Theresa's Catholic

Church, Madala in Niger State, the 2012 Easter bombing in Kaduna, the recent massacre of innocent students at college of Agriculture Yobe State and so many other target bombings and shootings in Kaduna, Kano, Bauchi, Plateau and Gombe states. Analysts are quick to blame the Boko Haram catastrophe on unemployment, hunger and deprivation. Specifically, the U.S government submitted that illiteracy, unemployment and inexorable demands of survival from the effects of poverty make the northern youths vulnerable and ready for recruitment into crime and social vices including terrorism of the Boko Haram genre.

The catalyst for violence in the Niger Delta, where the country's energy sector is concentrated could be grouped into two:

1. The indigenous populations dissatisfaction with their impoverished condition despite the wealth generated by the area's resources, and

2. The environmental degradation caused by energy- related development.

This disenchantment has spawned many militant groups prominent of them being the Movement for the Emancipation of the Niger Delta (MEND). MEND is seeking a more equitable distribution of Nigeria's oil wealth so that it benefits the local population, particularly the indigenous Ijaw tribe. In early 2006, MEND militias started attacking oil installations and kidnapping foreign oil industry workers in an effort to press home their demand. These actions led to a 20 percent reduction in Nigeria's oil production, (http://www.mongabay.com/reference/new-profiles/344. html) and have since been short- circuiting the government's budgetary projection from the oil sector.

Another form of internal security challenge in Nigeria is sectarian violence. It has been estimated that this alone has wasted over 10,000 lives since 1999. Every little event triggers off suspicion, hatred and killing between the Muslims and Christians in the northern part of the country 
and among the various ethnic nationalities. For instance, the recent communal clashes in Nasarawa and Plateau States.

Iredia (2011) citing the National Bureau of statistics, stated that there are about 35 million unemployed youths in the country who are forced to resort to anything that can serve as a means of livelihood. Former President Obasanjo in recent time raised the alarm that Nigeria may witness the type of revolution sweeping across the Arab world if nothing was done to redress the problem of youth unemployment. President Jonathan laid credence to this when he stated at the governorship election campaign in Lokoja that a revolution by the youths was imminent if elected public officials took no steps to initiate policies that would create jobs. J ob security is important so that citizens can live meaningful lives and secure their homes, children, wives, ageing parents and other dependent relatives. Unfortunately, low priority which social security is getting now over issues like job creation shows that for us, prevention is not better than cure and we prefer to deal with the symptoms instead of the root causes of the challenges.

There are also security challenges from food, water and health. National security starts with the social security component as represented by health care, food, shelter and clothing. The worsening economic conditions have been generating a mix of domestic, social and political tension. Governments are often expected to provide their citizens with political stability and socioeconomic security including health care and shelter. Lack of these basics often breeds discontents and social unrest. Tranquility and well- being of a society are necessary components of national security. Oshio (2009) observed that the Fundamental Objectives and Directive Principles of State Policy under the 1999 constitution of Nigeria contain many social- economic and political rights which, if fully implemented, would go a long way towards ensuring national security and development. These rights, he went further to state, are comparable to the Economic, Social and Cultural Right adopted by the United Nations General Assembly in 1966. Despite availability of resources the Nigeria State has failed to take necessary steps to give effect to these rights. This accounts in part to the intractable conflicts in the country.

Water resources management would yield more security dividends to the nation than many other sectors. It is a very essential requirement. When it is too much, it causes flooding and erosion with its trail of catastrophe. When it is scarce, it can cause drought and have a significant toll on agricultural production. These two conditions necessitate judicious and prudent management of our water resources.

At the political level, desperate, intolerant and ruthless contests among politicians and their followers have often resulted in violence, security breaches, killings and destruction, all of which threaten the existence of the Nigerian State. There are violent and desperate politickings among political parties, electoral fraud and money politics. The table below presents a tip of the iceberg into an aspect of electoral fraud in two states using the 1991 governorship election

Table 1: An Aspect of Electoral Fraud in 1991 Governorship Election.

\begin{tabular}{|c|c|c|c|c|c|}
\hline State & $\begin{array}{c}1991 \\
\text { Census } \\
\text { (Including } \\
\text { children) }\end{array}$ & $\begin{array}{c}\text { Eligible } \\
\text { voters }\end{array}$ & $\begin{array}{c}\text { Registered } \\
\text { voters }\end{array}$ & $\begin{array}{c}\text { Excess voters / } \\
\text { over } \\
\text { Registration }\end{array}$ & Percentage \\
\hline Akwa Ibom & $2,359,736$ & $1,061,881$ & $3,895,623$ & $2,176,824$ & 137 \\
\hline Imo & $2,485,499$ & $1,118,474$ & $2,541,962$ & $1,423,488$ & 102 \\
\hline
\end{tabular}

Note: There were a total of $24,448,488$ excess voters nationwide.

Source: Abubakar, A. (2005).

Electoral fraud poses a major challenge to democracy in Nigeria and by implication, a threat to the security of the nation. It generates resistance from those who believe they have been cheated out and they often will resort to violence. Money politics breeds a set of violent able-bodied young men 
riddled with poverty, illiteracy and half education being used as thugs to rig elections for monetary reward at the risk of their lives.

Kidnappings are now daily routine that attract little media attention or coverage unless high profile targets are involved. Armed robbery reigns in many parts of the country and big target hits like banks are not rare anymore. Land disputes and other ethnic upheavals have created a lot of security breaches in different parts of the country. To read our National Dailies is to read a "manifesto" on insecurity. All these have led us to where we are now today - mass poverty, insecurity of life and property, violent conflicts, armed robbery, kidnapping, poor quality of infrastructure and decay of social services.

\section{Proper Education: Panacea for Security Challenges in Nigeria}

Education has earlier been defined as a process by which individuals are assisted formally through proper direction and guidance to develop their capacities for their own benefits and that of the society. It therefore follows, by a simple logic, that if a nation bequeaths the right type of education to its citizens, the citizens will not turn against their father- land. Daily Sun (2013) recently reported the former minister of Education, Professor Ragayyatu Rufai as having identified reform of the education system as the solution to the security challenges confronting the nation. There is need for a total overhaul of the curriculum at all levels of education with a view to providing its recipients, broad based education in the development of the mind, soul and body; and in comprehending the environment and in the development of appropriate attitudes, skills, abilities and competences to co-exist with and contribute to the development of the society. This calls for a synergy between liberal education, vocational and entrepreneurship education.

A liberal education is one that frees the minds of its recipients from their preconceptions. It broadens the possibilities for greater understanding of others in our nation and around the world (Forum Futures, 2007). Institutions should try to train future workers to help States' economies and to offer liberal education so as to produce informed citizens who can contribute to our democratic way of life.

Every sovereign, independent state must train, sustain and nurture men and women to serve in its security and intelligence out fits. According to Esiemokhai (2005), in Europe and America, these men and women are selected from the best and the brightest citizens, who are endowed with keen and subtle intellect. Recruitment into defense and military intelligence outfits needs scrupulous assessment of the recruit's educational background, intellectual sharpness, smartness and patriotism. Graduates with the best grades should be deployed not those who got ranks by the federal character formula

Education helps to create informed citizenry which is vital to our democratic society. It increases the potential for individuals to perform as citizens. There are many examples of the public being misinformed and making bad decisions. However, without education, the situation would be vastly worse. It gives one the ability to critically examine an issue and articulate a reasoned position about it. Nurturing critical thinking is a key component of education.

The introduction of Vocational and Entrepreneurship programmes into the curriculum at the various levels of education in Nigeria is a welcome innovation that goes a long way to strengthening the popular liberal education. What is required by the government at various levels now is to adequately provide the needed human and material resources to make these programmes effective and functional. It is no longer news that liberal education alone has failed to equip recipients / youths with requisite skills and attitudes for leading a productive life. It is also no news that graduates of our institutions of higher learning have been populating the crime world due to their inability to secure meaningful employment upon graduation. This scenario calls for the intensification of the emphasis on Vocational and Entrepreneurial education to equip graduates with occupational survival skills - to be able to identify and even create and exploit investment opportunities that abound in the society. The present global economic crises and rising waves of 
unemployment have greatly emphasized the need for functional entrepreneurship and vocational education.

There is also the need to introduce Nigerian History, Moral and Civic education into the curriculum. Graduates should actually be found worthy first in character and then in learning. Every youth should see himself / herself as a stakeholder in the Nigerian project, by exercising all requisite citizenship roles and responsibilities. It should be inculcated in our children at the early age the respect for human life and the dignity of labour. Civic education will place youth on a sound pedestal to defend our nascent democracy instead of being destructive agents. A poor knowledge of our national history will hinder informed citizenry which is required for rapid development of the nation. A citizen who does not know his country cannot really situate himself within the effort to build a better nation (Daily Sun, 2011).

\section{Recommendations}

Sequel to the revelations and implications of this discourse, the following recommendations become imperative.

1. Stakeholders in the education industry should form a more lasting synergy to guarantee adequate funding of the system since all aspects of the curriculum from time to time need some innovations which introduction is cost intensive.

2. Regular revision and introduction of innovative curricula such as in Family living Education, Entrepreneurship Education will go a long way to assuaging some of the existing gaps in pupils acquisition of the right attitude to life and work.

3. There is need for a review of our education curriculum to include critical subjects that are necessary for development of informed and well rounded citizens. There is no doubt that a good knowledge of certain subjects such as our national history and civics will help in the development of more socially aware youths, truly literate and educated citizens who understand and appreciate the nation's peculiar challenges and can situate themselves within the search for solutions to the problems. Through the curriculum used in our schools, we need to develop citizens that are truly Nigerians at heart and care about the challenges facing our country.

4. There is the need to devise strategies for effectively controlling of all forms of examination malpractice in both internal and external examination to ensure quality graduates.

5. Following from all the above, there is the need to urgently reform the nation's education system with a view to making it more qualitative and responsive to emerging global issues as well as to the current national economic reform agenda. The restructuring should aim to achieve increased depth in content, incorporation of ICT in the curriculum, strengthening the entrepreneurial education component of the programme, removing areas that are not very important in achieving the desired goals and extending time for practical teaching.

6. Government/agencies should reassess the position of private school entrepreneurs taking cognizance of the roles of the "magic" or "miracle" centers that have contributed in no mean way in exacerbating the problem of examination and certificate racketeering.

7. Youth unemployment should be addressed through creation of data bases that can furnish economic planners strategic options in employment creation,

8. Government - private partnership should evolve a strategy for re-awakening most of our moribund industries to create employment opportunities for youths.

9. There is the need for re-inventing the agricultural sub-system of the economy, through emphasis on food and cash crop production as well as ways of adding value to farm products through processing.

10. School-industry linkage should be strengthened as a way of giving meaning and effect to the current drive on Technical and Vocational Education and Training (TVET) to encourage 
acquisition of work skills.

\section{Conclusion}

There are unrests of various shades and hues in different states of Nigeria, borne out of equally diverse causative factors. This paper has identified different national security challenges. All these threaten the very existence of the nation. The country cannot afford to be indifferent and noncommittal to these issues of national security challenges. In response, the government has continued to allocate the lion share of our nation's budget to security. The generous security budget gives the impression that what we need to worry about is the security problem caused by deviants. There are security problems posed by natural disasters e.g. flooding, desertification etc; and from youth unemployment. We also have security threats from hunger and filthy environment which can lead to such deadly diseases as malaria, diarrhoea, typhoid and Lassa fever etc.

The security of the high ways and bye-ways will enable mobility and free movement of people. The extra- budgetary expense on "security" has not succeeded in dousing the security challenges in the country. Security must insulate security bigots, illiterates, haters of their own people, so that they do not cause trouble. A State must manage its resources well to provide the basic needs for its citizens.

There is no doubt that the security situation in the country calls for extraordinary measures to combat it. It will need a transformation in the way we think and in the way we look at one another. The education option comes in handy for the desired transformation. It may take a long time and huge resources to achieve but the end is certainly going to justify the means. Nigerians should perceive the education option as a new way to reduce the sophistication of crimes and violence that are threatening national integration and security.

\section{References}

Abubakar, A (2005). The challenges of security in Nigeria. Newswatch, Monday, February 21.

Afegbua, P.K. (2012). State of the Nation. Saturday Sun, January 7, P. 7.

Daily Sun (2011), Daily Sun Comment, Thursday, April 7, P.18.

Daily Sun (2012). Boko Haram: Borno will rise again. Daily Sun, Thursday, March 15,

Daily Sun (2013), Rufai Foresaw her sack 24hrs before. Thursday, September

Esiemokhai, E.G. (2005). Military intelligence and international law. Heidellers, Germany; international law.

Esiemokhai, E.O. (2010). National Security in Nigeria. Published March $23^{\text {rd }}$.

Forum Futures (2007). Higher Education and National Security. Forum for the future of higher education, Cambridge, mass.

http://www.mongabay.com/reference/new-profiles/344.html.

I redia, T. (201 1). What is National security? Nigeria Today, December 18.

Matawal, D.S. (2007). Teacher Preparation for National Educational Reforms: A Keynote address. Bichi Journal of Education, PP. 1-9

Okeke, C.C. (2003). Philosophy of Education. Owerri: Design Prints Publishers.

Oshio, Ehi (2009). The Challenge of National Security and Development. A paper delivered at the Delta State Christian Professional League Seminar on Crises Management and Nation Building at Grand Hotel, Asaba, on Thursday $19^{\text {th }}$ November. 
